\title{
Konsep Kepribadian Guru: Perspektif Historis
}

\author{
Isti'anah Abubakar \\ Dosen Fakultas Tarbiyah Universitas Islam Negeri (UIN) Malang
}

\begin{abstract}
Teaching is perceived as a very heavy duty, but for other, teaching is the art and full charity. Teacher is really person who teach pupil to rich the best life. But, in turn, public does not care to the teaching profession. New generation are seemingly are not interested to enter the profession. Improsperity of teacher's life is the main factors of public's undesirable to the teaching profession, this is the problem. Based on the phenomena or reality, there are many ways produced to solve the problem. One of them is Public Regulation of Teaching Profession ( $U U$ No. 14 Th.2005 Tentang Guru Dan Dosen). We realize that regulation is not the mere solution. We recommend that teacher's personality and performance have to improve to the ideal one and it is the important way to solve.
\end{abstract}

Keywords: teacher, personality, profession

\section{A. Pendahuluan}

Guru merupakan profesi yang mengalami pasang surut dalar percaturan dunia keprofesian. Kalaulah dulu guru dianggap sebagaii profesi sakral, membanggakan yang terlihat ketika dengan bangganya seseorang yang bermantukan seorang guru, tapi saat inii guru disinyalir menjadi profesi yang termarginalkan. Ini terlihat darii banyaknya generasi penerus yang sedikit bercita-citakan sebagai guru. Mereka cenderung menjadikan dokter, insinyur, pilot, sebagai pilihan profesi di masa depan. Ada berbagai macam alasan yang dikemukakan akibat ketidakmauan mereka, namun yang jelas segii kesejahteraanlah yang menempati urutan pertama bagi seseorang untuk tidak memilih guru sebagai profesinya.

Fenomena di atas disebabkan adanya pergeseran dalam memaknai profesi seorang guru. Pergeseran ini disebabkan beberapa faktor, baik faktor eksternal maupu faktor internal. Faktor eksternal di.antaranya: 
1. Adanya pandangan sebagian masyarakat bahwa siapapun dapat menjadi guru asal dia berpengetahuan.

2. Kekurangan guru di daerah terpencil memberikan peluang untuk mengangkat seseorang yang tidak mempunyai keahlian (mendidik) untuk menjadi guru.

3. Banyak guru yang belum menghargai profesinya apalagi berusaha mengembangkan profesinya tersebut. Perasaan rendah diri karena menjadi guru, penyalahgunaan profesi untuk kepuasan dan kepentingan pribadi.

Sedangkan faktor internal yang dimaksud adalah adanya kelemahan yang terdapat pada diri guru itu sendiri di antaranya rendahnya kompetensi profesional mereka

Kesemuanya itu sudah menjadi wacana umum yang terus dicari pemecahannya, terutama di akhir tahun 2005 dengan akan disahkannya UU profesi guru dan dosen. Namun demikian perlu disadari bersama, bahwa UU tersebut bukan satu-satunya solusi yang dapat mendongkrak popularitas profesi guru. Naiknya popularitas guru hanya akan terjadi bila guru secara pro aktif meningkatkan kapasiitasnya sebagai guru. Artinya, UU tersebut tidak akan berdaya guna secara maksimal bila guru sendiri kurang greget dalam meningkatkan kualitas dia sebagai seorang guru.

Akankah hal semacam ini berlangsung di masa datang inilah yang hendak dibahas untuk kemudian mendapatkan kejelasan dan pemapingan atas apa yang terjadi dalam profesi keguruan.

\section{B. Pembahasan}

Kepribadian guru mempunyai kelebihan sendiri bila diterapkan dalam kelas karena ia akan memberikan kecenderungan dan kesenangan yang berbeda kepada murid. Namun ada juga yang mengatakan bahwa kepribadian guru sulit ditemukan kadarnya dan tidak mudah untuk dicari batasannya serta sulit pula untuk didefiniskan secara jamik dan manik. Kepribadian juga diibaratkan seperti magnit, listrik dan radio yang tidak bisa diketahui kecuali setelah kita tahu bekasnya atau pengaruhnya. 
Kepribadian ialah kumpulan sifat-sifat yang aqliah, jismiah, khalqiyah yang dan iradiah yang biasa membedakan seseorang dengan orang lain (Slamet Yusuf:37).

Dikatakan guru yang mahir adalah guru yang mampu untuk menundukkan hati mereka dan mempengaruhi mereka dengan baik sehingga ia dapat memerintah mereka dan berbicara dengan mereka. Maka dengan kepribadian itu memungkinkan untuk mengarahkan mereka pada jalan yang lurus.

Umar bin Utbah (dalam Slamet Yusuf :39), berkata pada guru dari anaknya sbb: "Hendaklah perbaikan pertama-pertama yang engkau lakukan terhadap anak saya dilakukan dengan perbaikan dirimu maka mereka akan tertuju padamu, yang mereka anggap baik adalah apa yang engkau tinggalkan. Menurut Mr. Norman Mc. Munn (Slamet Yusuf:41), kepribadian itu didapat dari latihan yakni dari kebiasaan dan pendidikan yang sungguhsungguh. Tokoh pendidikan dari Inggris, Sir T.Percy Nunn mengatakan bahwa tujuan pendidikan adalah mendidik kepribadian (Andreas Hafera, 2000).

Kepribadian itu bisa membangkitkan semangat, tekun dalam menjalankan tugas senang memberi manfaat kepada murid menghormati peraturan sekolah sehingga membuat murid bersifat lemah lembut memberanikan mereka, mendorong pada cinta pekerjaan, memajukan berfikir secara bebas tetapi terbatas yang bisa membantu membentuk pribadi menguatkan kepribadian menguatkan kehendak membiasakan percaya pada diri sendiri.

Suksesnya seorang guru tergantung pada kepribadian, luasnya ilmu pengetahuan tentang materi pelajaran serta banyaknya pengalaman. Tugas seorang guru itu sangat berat, tidak mampu dilaksanakan kecuali apabila kuat kepribadiannya, cinta dengan tugas, ikhlas dalam mengerjakan memelihara waktu murid, cinta kebenaran, adil dalam pergaulan. Ada yang mengatakan bahwa masa depan anak-anak di tangan guru dan di tangan gurulah terbentuknya umat.

Ditulis Athiyah Al-Abrosy (dalam Slamet Yusuf: 42) bahwasannya sifat-sifat yang seyogyanya dimiliki seorang guru:

1. Guru harus menjadi bapak sebelum ia menjadi pengajar. 
2. Hubungan guru dengan murid harus baik.

3. Guru harus selalu memperhatikan murid serta pelajaran mereka.

4. Guru harus peka terhadap lingkungan sekitar murid.

5. Guru wajib menjadi contoh/teladan di dalam keadilan dan keindahan serta kemuliaan.

6. Guru wajib ikhlas di dalam pekerjaannya.

7. Guru wajib menghubungkan masalah yang berhubungan dengan kehidupan

8. Guru wajib selalu membaca dan mengadakan penyelidikan

9. Guru harus mampu dalam mengajar bagus penyiapannya dan bijaksana dalam menjalankan tugasnya

10. Guru harus sarat dengan ide sekolah yang modern

11. Guru harus punya niat yang tetap

12. Guru harus sehat jasmaninya

13. Guru harus punya pribadi yang mantap

\section{Guru ditempatkan pada tempat yang mulia sesuai dengan} hadits Nabi

Pada suatu hari, Rasulullah keluar rumah kemudian beliau melihat ada 2 majlis. Majlis yang satu terdiri dari orang yang berdoa kepada Allah dan mengharap kepadaNya. Majlis kedua terdiri dari jamaah yang mengajarkan agama kepada manusia. Beliau bersabda Adapun yang itu (yang pertama) mereka memohon kepada Allah jika Dia berekanan mereka akan diberi dan Dia juga berkenan untuk tidak memberi. Dan yang itu (kedua) mereka mengajari manusia, dan bahwasannya aku diutus adalah hanya untuk mengajar. Kemudian beliau maju dan ijkut duduk pada kelompok ke-2. Dengan demikian Nabi yang mulia telah membuat sebaik-baik contoh buat kita agar menjadi pengajar dan pendorong dalam mengajar serta mengakui keutamaannya.

Demikian juga seperti yang dikatakan Martin Luther: "Jika aku mempunyai waktu untuk meningggalkan tugas memberi nasehat dan memberi petunjuk pasti aku akan memilih profesi sebagai pengajar. 
Ucapan Bismark: "Sungguh kami telah dipengaruhi oleh guru." Senada dengan itu Iramus dalam ucapannya: "Berilah aku kantor untuk guru dan aku berjanji kepadamu dengan hati seorang berilmu. Sedangkan Syauqi Bik: "Berdiri dan hormatilah guru dan berilah ia penghormatan." Hampir-hampir saja seorang guru itu merupakan utusan.

"Hai Ben Sherira, curahkanlah segenap tenagamu untuk mengajar anak-anakmu sewaktu masih kecil dan berikanlah hadiah kepada guru atas jasanya karena apa yang kamu berikan adalah diberikan untuk anakanakmu," Ungkap Ustadz Al Alim Al Muhiqq Ahmad Amin.

Mengajar adalah pekerjaan yang memayahkan, tidak mendatangkan harta dan tidak memperoleh pangkat. Mengajar itu hanya pantas dan bagus bagi orang yang qana'ah terhadap masalah dunia dengan hidup sederhana dan dalam pembagian rizki yang sangat sempit. Guru yang fasid adalah guru yang menjadikan harta dan pangkat sebagai tujuan utama dan mengharapkan keduniaan. Mengajar adalah pekerjaan jiwa. Guru itu menciptakan dirinya dan amalnya ke langit, keluarganyalah yang menariknya ke bumi dengan kekerasan.

Apakah dia rela berkorbang seperti berkorbannya tentara?apakah dia siap menerima kenyataan untuk bertapa seperti pendeta apakah dia siap berhibur dengan harta ma'nawi untuk meningggalkan yang materi dan membentuk dirinya sebagai orang berilmu yang qänaah serta menempatkan kelezatan-kelezatan akal dan rohani pada kelezatan badan?"

Seorang penulis Inggris (dalam Slamet Yusuf :32) mengatakan:" kurikulum, peraturan sekolah, bangunan-bangunan yang besar dan peralatan dalam pendikan dan pengajaran tidaklah lebih penting dari guru karena guru mempunyai pengaruh besar di hadapan siswa dari sebab ilmunya, etikanya, perbuatannya dan ketrampilannya.

Fesyar pernah menyerukan tahun 1917 (dalam Slamet Yusuf :35) bahwa guru hendaknya sudah tidak merasa kesulitan lagi dalam masalah keuangan atau kebutuhan hidupnya karena tugas pokok mereka adalah mengelola pendidikan bagi guru yang sudah kawin hendaknya mempunyai kondisi sosial ekonomi yang sudah mapan sehingga mampu mendidik keluarganya dengan baik. Seorang guru yang susah, begitu juga 
seorang guru yang miskin akan mendapat kesan kurang baik di tengahtengah masyarakat

Tugas guru dapat disimpulkan mempunyai 3 tugas pokok, yaitu : (1) Tugas dalam bidang profesi yang meliputi mendidik, mengajar, dan melatih. Tugas guru dalam hal ini dituntut untukselalu mengembangkan profesionalitas diri sesuai perkembangan IPTEK, (2) tugas dalam bidang kemanusiaan, memposisikan dirinya sebagai orang tua kedua (Usman,2002:7) (3) tugas dalam bidang kemasyarakatan dalam hal ini pembelajarn seperti dikutip Usman dari Adfams dan Decey dalam Basic Principles of Student meliputi: (a) guru sebagai demonstrator, (b) sebagai pengelola kelas, (c) sebagaimediator dan fasilitator, (d) sebagai evaluator. Sedangkan menurut Djamarah $(2000,44)$ meliputi: (a) sebagai inspirator, (b) sebagi informator, (c) sebagai organisator, (d) sebagai motivator, (d) sebagai inisiator, (e) sebagai pembimbing, (f) sebagai uswah (teladan atau model), (g) seabagai penasehat.

\section{Kompetensi :Kepribadian}

Kompetensi secara bahasa diartikan kemampuan atau kecakapan. Hal ini diilhami dari KKBI dimana kompetensi diartikan sebagai wewenang atau kekuasaan untuk menentukan atau memutuskan suatu hal. Sedangkan menurut Partanto (1994), dalam Kamus Ilmiah Populer, kompetensi diartikan sebagai kecakapan, wewenang, kekuasaan dan kemampuan. Sedangkan secara terminologis, sebagai berikut:

1. Menurut Broke and Stone, gambaran hakekat kualitatif dari perilaku guru yang tampak sangat berarti.

2. Mc Leod dalam Usman (2001), keadaan bèrwenang atau memenuhi syarat menuntut ketentuan hukum.

3. Jhonson, perilaku yang rasional untuk mencapai tujuan yang diprasyaratkan sesuai dengan kondisi yang diharapkan.

4. Pengertian lain diartikan sebagi kemampuan dasar yang mengaplikasikan apa yang seharusnya dapat dilaksanakan oleh seorang guru dalam melaksanakan tugasnya. 
5. Menunjuk pada kemampuan melaksanakan sesuatu yang diperoleh melalui pendidikan dan pelatihan.

6. Hitami dan Sahrodi (2004), pemilikan nilai, sikap dan ketrampilan yang diperlukan dalam menyelesaikan suatu pekerjaan.

7. McAshan dalam Mulyasa (2003:38) sebagai pengetahuan, ketrampilan dan kemampuan yang dikuasai seseorang yang telah menjadi bagian dari dirinya sehingga ia dapat melakukan perilaku-perilaku kognitif, afektif dan psikomotorik dengan sebaik-baiknya.

8. Finch dan Crunkilton (1979:222) merupakan penguasaan terhadap suatu tugas, ketampilan sikap dan apresiasi yang diperlukan untuk menunjang keberhasilan.

9. Kemampuan seorang guru dalam melaksanakan kewajiban secara bertanggung jawab dan layak.

Aspek kompetensi menurut Gordon dalam Mulyasa (2003:39),

1. Pengetahuan

2. Pemahaman

3. Kemampuan

4. Nilai

5. Sikap

6. Minat

Jenis kompetensi, meliputi di antaranya: (a) Kompetensi personal, (b) kompetensi profesional, (c) kompetensi sosial meliputi (a) trampil berkomunikasi dengan orang lain, (b) bersikap simpatik terhadap siswa dan masyarakat, (c) dapat bekerjasama dengan orang lain, (d) pandai bergaul.

Kompetensi personal, yaitu sikap pribadi guru yang dijiwai oleh agama dan filsafat pancasila yang akan mengagungkan moral dan budaya. Dan ini mencakup kemampuan dan integritas pribadi, peka terhadap perubahan dan pembaharuan, berpikir alternatif, adil, jujur, obyektif, disiplin, ulet, tekun, simpatik, menarik, luwes, terbuka, kreatif dan berwibawa Kompetensi personal bisa diidentikkan dengan kepribadian dan 
kepribadian yang baik akan berpengaruh terhadap hidup dan kebiasaan belajar para siswa. Untuk memiliki kepribadian yang baik ini guru dituntut memiliki kematangan dan kedewasaan pribadi serta jasmani dan rohani, dan cirinya adalah sbb: (1) memiliki pedoman hidup, (2) mampu melihat segala sesuatu secara obyektif, (3) mampu bertanggung jawab

Ciri guru yang profesional dikutip dalam Jurnal Educationl Leadership (1998): (1) mempunyai komitmen pada siswa dan proses belajarnya, (2) menguasai secara mendalam bahan pelajaran yang diajarkannya serta metode pembelajaran yang relevan, (3) bertanggúng jawab dalam memantau hasil belajar melalui berbagai cara evaluasi, (4) mampu berpikir sistematis tentang apa yang dilakukannya dan belajar dari pegalamnanya, (5) guru seyogyanya merupakan bagian dari masyarakat belajar dalam lingkungan profesinya

Yang mempengaruhi rendahnya profesionalisme guru, menurut Akadum (1999) (1) masih banyak guru yang tidak menekuni profesinya secara total, (2) rentan dan rendahnya kepatuhan guru terhadap norma etika profesi keguruan, (3) pengakuan terhadap ilmu pendidikan dan keguruan masih setengah hati, dll.

Jihad oleh Muhaimin (2003:230-231) diartikan sebagai makna kesediaan bekerja keras dengan mencurahkan segala kemampuan, baik fisik/materi maupun totalitas dirinya menuju jalan Allah, mempunyai sikap ketelitian dan kecermatan, serta terbuka terhadap kritik dari luar, mempunyai kebanggaan terhadap pekerjaan yang bermutu (bukan asal kerja) dan mempunyai wawasan jangka panjang (harapan masa depan)

Mengenai keejahteraan guru menurut Komball Wiles (dalam Bafadal, 2003:101-102), ada 8 hal yang diinginkan guru melalui kerjanya (1) adanya rasa aman dan hiodup layak, (2) kondisi kerja yang menyenangkan, (3) rasa diikutsertakan, (4) perlakuakn yang wajar dan jujur, (5) rasa mampu, (5) pengakuan dan penghargaan atas sumbangan, (7) ikut ambil bagian dalam pembuatan kebijakan sekolah, (8) kesempatan mengembangkan self respect.

Pembahasan diatas semakin mempertajam adanya keterkaitan yang kuat antara kompetensi dan kepribadian guru. Keduanya-secara 
bersamaan- mencoba untuk merealisasikan profil guru ideal dari berbagai sudut pandang baik personal, soaial dan akademik.

\section{Kepribadian Guru dalam Perspektif Historis}

\section{a. Profil Guru di masa dulu}

Secara singkat telah dijelaskan di atas bahwa profesi guru di masa dulu merupakan profesi idaman, dimana semua orang ingin menjadi guru, kalau toh tidak berhasil sekedar bermantukan guru saja pun sudah bangga.

Kebanggaan yang mendarah daging dimasa lalu ini merupakan sesuatu yang manarik untuk dikaji, ada apa dengan guru sehingga menjadi profesi yang sangat diminati? Padahal kalo dilihat secara kasad mata, dari segi kesejahteraan sangat jauh dari kurang, namun demikian mereka selalu mendapatkan tempat tertinggi dalam tatanan masyarakat pada waktu. Guru benar-benar diposisikan dan dihargai.

Bila bukan dari aspek kesejahteraan, pastilah ada aspek yang sangat fenomenal dalam profesi guru itu sendiri. Sosok, Ki Hajar Dewantara merupakan sosok yang mewakili profil guru di masa lalu. Artinya, bila ingin mengetahui secara detail tentang profil guru masa lalu maka amatilah bagaimana kepribadian beliau. Sosok guru sebagai pahlawan tanpa tanda jasa benar-benar dapat diamati, tak ada batasan waktu, tempat dalam mengajarkan ilmu dan yang paling penting mereka betul-betul the ideal model. Apa yang dikatakan dan apa yang dilakukan sejalan yang secara tidak langsung menimbulkan kewibawaan sejati dalam diri beliau.

Kepribadian semacam inilah yang kemudian menjadikan murid-murid beliau termotivasi untuk menjadi guru sekaliber $\mathrm{Ki}$ Hajar Dewantara. Ini sesuai dengan statement yang mengatakan bahwa pribadiguru itu besar sekali pengaruhnya terhadap keberhasilan darma baktinya dan guna berpengaruh pada muridnya. 
Namun demikian harus juga dipahami bahwa bukan hanya kepribadian saja yang menentukan keberhasilan tugasnya sebagai guru tetapi harus pula dilengkapi dengan ilmu khusus, kebudayaan tertentu dan persiapan pelayanan yang teratur.

Artinya bisa dikatakan profil guru di masa lalu adalah profil guru ideal, dimana mereka mumpuni dan matang dalam aspek kepribadian, keilmuan dan perilaku yang semua itu kemudian dilengkapi dengan semangat pengabdian atau menurut Muhaimin identik dengan semangat jihad. Jihad oleh diartikan sebagai makna kesediaan bekerja keras (denganmencurahkan segala kemampuan, baik fisik/ materi maupun totalitas dirinya) menuju jalan Allah, mempunyai sikap ketelitian dan kecermatan, serta terbuka terhadap kritik dari luar, mempunyai kebanggan terhadap pekerjaan yang bermutu (bukan asal kerja) dan mempunyai wawasan jangka panjang (harapan masa depan).

Secara lebih dalam, profil guru masa lalu bisa diamati dalam sajak berikut ini:

Siapa Guru Bangsa Ini?

Anda dan saya!

Yang berarti kita. Semua tak terkecuali

Termasuk pak Lurah adalah guru bangsa ini ketika

Dengan senyum membuatkan KTP bagi si Bejo

Tanpa rasa pamrih. Juga Pak darmo yang sopir bus

Adalah guru bangsa ini ketika mempersilahkan

Kendaraan lain yang mau menyalip untuk mendahului.

Demikian pula Pak Budi yang pengusaha adalah guru bangsa ini

Ketika membuang limbah tanpa merusak lingkungan.

Tak terkecuali Pak Edi, pejabat yang senantiasa

Lebih dulu memberi salam selamat pagi kepada

Bawahannya, dia adalah guru bangsa ini. 
Atau si Udin, adalah guru bangsa ini ketika membuat sumur Tidak pernah menipu soal kedalam sumurnya.

Mereka semua adalah guru bagi bangsanya.

Termasuk Anda dan Saya.

Kalau bukan kita, siapa lagi yang mau membimbing

Negeri ini agar lebih baik dan lebih maju.

Perlukah kita mendatangkan guru-guru dari negara-negara lain?

Relakah kita bila kita digurui oleh bangsa-bangsa lain?

Atau maukah kita terus-terusan menjadi murid bagi bangsa ini?

Kita semua wajib menjadi guru bagi kemajuan bangsa ini. ( Dikutip dari Tilaar, 1999: 333)

\section{b. Profil Guru Masa Kini dan Akan Datang}

Kemerosotan profesi guru baik di dalam minat pemuda kita untuk memasukinya maupun oleh masyarakat yang kurang memberi perhatian atau penghargaan terhadap profesi guru menunjukkan adanya keharusan untuk mencari paradigma baru supaya profesi guru memenuhi tuntutan masyarakat baru dalam milenium ketiga. Perlu disadar bahwa fungsi dan peranan guru bisa berubah tapi profesi guru akan selalu tetap dibutuhkan.

Sebelum menganalisi tentang profil atau kepribadain guru masa kini dan akan datang maka perlu diketahui karakteristik masyarakat yang dihadapi yang notabene merupakan konsumen atau pengguna jasa pendidikan.Menurut Tilaar (1999: 281), ada 3 karakteristik masyarakat masa kini dan akan datang (= masyarakat milenium 21), yaitu:

1) Masyarakat Teknologi, dimana kemajuan teknologi sangat berkembang pesat sehingga membuat dunia menjadi satu, sekatsekat yang membatasi bangsa-bangsa, pribadi-pribadi menjadi hilang sehingga bentuk-bentuk komunikasi umat manusia akan berubah. 
2) Masyarakat terbuka, pada jenis ini dibutuhkan manusia yan $g$ mampu mengembangkan kemampuan dan yang mampu berkerasi untuk peningkatan mutu kehidupannya serta sekaliogus mutu kehidupan bangsa dan masyarakatnya

3) Masyarakat madani, yaitu masyarakat yang saling harga-menghargai satu dengan yanglain, yang engakui akan hak-hak asasi manusia yang menghormati akan prestasi dari para anggotanya sesuai dengan kemampuan yang dapat ditunjukkannya bagi masyarakat.

\section{c. Deskripsi Profil Guru Masa Kini}

Untuk memahami posisi guru masa kini, dapat dipahami dari sajak-sajak berikut:

Sejuta batu nisan

Guru tua yang terlupakan sejarah

Terbaca torehan darah kering

Disini berbaring seorang guru semampu membaca buku usang Sambil belajar menahan lapar (Kompas, 26 Desember 2006).

Dari puisi diatas dapat dipahami ada 3 pesan global yang disampaikan Winarno, yaitu:

1) Adanya kecenderungan profesi guru terlupakan .Senada dengan ini, Tilaar juga mengatakan bahwa profesi guru diambang kematian karena bukan saja tidak diminati oleh putra bangsa yang terbaik juga karena masyarakat sendiri tidak memberikan penghargaan yang wajar terhadap profesi guru. (Tilaar, 1999:285). Padahal untuk mengatasi itu semua diperluykan suatu penghargaan masyarakat, karena suatu profesi akan hidup dan berkembang apabila tersebut dihargai oleh masyarakat. Dan ini ditunjukkan dengan adanya keinginan masyarakat untuk memilih profesi sebagai suatu unggulan (Tilaar,1999: 291). 
2) Kemampuan finansial yang amat memprihatinkan. Tilaar dalam hal ini mengatakan bahwa imbalan ekonomis dalam sektor modern lebih besar daripada profesi yang tua seperti guru dan petani. (Tilaar,1999:285).

3) Pentingnya mengembalikan guru sebagai profesi suci, mengingat banyak guru yang terjangkiti perilaku instan dan praktis.

Setelah kita melihat profil profesi guru Indonesia dewasa ini tentunya tidak dapat kita harapkan masyarakat kita dapat dibawa untuk memasuki masyarakat abad 21 yang kompetitif. Masyarakat kompetitif yang dikuasai oleh ilmu pengetahuan dan kemajuan teknologi khususnya teknologi komunikasi. Untuk itu profil guru yang dibutuhkan adalah:

1) Memiliki kepribadian yang matang dan berkembang (mature and developing personality)

2) Penguasaan ilmu pengetahuan dan teknologi yang kuat, hal ini diilhami dari surat Az Zumar ayat 9, " katakanlah apakah sama orang yang mengetahu dengan orang yang tidak mengetahui? Bahwasannya yang dapat mengambil pelajaran itu adalah oarng yang mempunyai akal dan juga dalam surat ash-Shaf ayat 2-3 " Hai orang-orang yangberiman mengapa kau mengatakan sesuatu yang tidak kamu perbuat? Amat besar kebencian Allah karena kau mengatakan sesuatu yang tidak kamu perbuat"

3) Ketrampilan membangkitkan minat peserta didik

4) Pengembangan profesi yang berkesinambungan.

\section{Analisis}

Uraian di atas menjelaskan secara kongkrit bagaimana meningkatkan popularitas profesi guru dimasa kini dan akan datang. Bila diklasifikasikan, maka penjelasan di atas hanya berkutat atau ditekankan pada aspek , (1) performansi (penampilan luar) seorang guru, (2) akademik, dimana guru dituntut untuk selalu belajar dan meneliti, (3) kesejahteraan guru. Ketiga 
hal di atas tidak balance sehingga yang terjadi protes akan rendahnya gaji yang diterima seorang guru sehingga harus ngompreng sana ngompreng sini.

Dari klasifikasi di atas, maka dapat langsung dikatakan bagaimana sebenarnya profil guru kita ini. Namun demikian, kesalahan tidak terletak pada guru sebagai person, tapi semua itu telah termasukkan dalam sistem yang sangat kuat sehingga diperluka kontinuitas untuk memperbaikinya.

Dari beberapa pembahasan tentang profesi guru di atas, penekanan yang diperjuangkan hanyalah pada masalah materiall sehingga sangatlah wajar bila kemudian salah satu pengajar UIN Jakarta dalam Swara Cendikia mengatakan bahwa sistem pendidikan kita sudah termatrialisasikan, artinya semuanya harus ada pelicin. Dan ini berimbas pada guru, dimana kita jumpai sangat minimnya jiwa pengabdian yang ada dalam diri guru, apalagi yang berada di perkotaan.

Selain minimnya semangat pengabdian $=$ jihad, minim pula sifat qonaah seorang guru sehingga terjadilah malapraktik pendidikan, baik dengan menjual nilai, nggompreng buku atau bahkan sampai jualan narkoba. Hal tersebut juga menunjukkan bahwa guru kita miskin kretivitas atau kureang liricah dalam menangkap peluang yang ada.

Sehingga kita tidak menyalahkan jika ada statement bahwa pekerjaan guru itu berat untuk itu dibutuhkan komitmen tinggi untuk melakoniya. Artinya jika profesi guru sudah pilihan kita, maka pastilah sudah disadari sejak awal bagaimana plus-minusnya profesi guru. Jika ini disadari secara mendalam, maka tidak akan ada protes sampai turun ke jalan hanya sekedar untuk memperjuangkan hak, padahal bila ditanyakan ulang sudahkan seorang guru melakukan kewajiban, karena notabene hak bisa diambil bila sudah melaksanakan kewajiban, baik kewajiban mengajar atau mendidik. Ini juga pernah dilakukan Socrates, di mana ia menolak gaji (Hasan ,1988, 187).

Menyikapi hal ini, hendaklah kita melakukan apa yang dikatakan Maslow sebelum hidunya berakhir dengan mengatakan, Ini senada dengan piramid Maslow yang telah dibalik, karena di akhir hidupnya Maslow mengatakan Every one should self actualize as a firts priority then for themselves people will be valued by others, loved by others, feel secure and survive. Bila 
dianalogikan, maka setidaknya guru harus melakukan sesuatu terlebih dulu untuk dapat dihargai (mis; baik itu dengan mengajar dengan maksimal). Bila ini sudah dilakukan maka secara otomatis, masyarakat ataupun pemerintah tanpa diminta pun akan menaikkan kesejahteraan guru.

Masalah pergeseran kepribadian guru dari waktu ke waktu dapat diperjelas dalam tabel berikut ini:

\begin{tabular}{|c|l|l|}
\hline NO & \multicolumn{1}{|c|}{ DULU } & KINI, AKAN DATANG \\
\hline 1. & Tanpa pamrih & No pamrih no service \\
\hline 2. & Komitmen tinggi & Komitmen angin-anginan \\
\hline 3. & Istiqomah & Istiqomahnya tergantung \\
\hline 4. & Qonaah & Kurang qonaah \\
\hline
\end{tabular}

\section{Keterangan:}

Bila mau dikomparasikan maka ke-3 hal di atas adalah profill guru di masa dulu dengan guru dimasa kini dan akan datang. Dan bila dipahami lebih lanjut, perbedaan terletak pada ruh pendidikan itu sendiri. Artinya pendidikan yang notabene lapangan pengabdian, seorang guru menggunakan paradigma yang berbeda. Bila dahulu paradigma yang digunakan adalah amal jariyah ansich. Ini semua termotivasi dari hadits Nabi tentang 3 amalan kekal yang salah satunya adalah amal jariyah, serta hikmah Arab

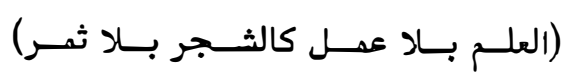

Sedangkan paradigma guru masa kini dan akan datang (merupakan prediksi, artinya bisa terjadi dan tidak), berpatokan pada mencari rezeki sebanyak-banyaknya. Karena rezeki yang dicari maka bila mendapatkan rezeki kecil akan kebingungan dan mencari obyekan lain. Prots gaji dan demo-demo lain merupakan akiobat logis dari paradigman yang digunakan tersebut. 
Selain itu bila seseorang telah memilih menjadi guru maka ia kan terjun total dalam bidang yang telah dipilihnya sehingga perilaku, ucapan dan tindakan selalu disesuaikan dengan profesi yang telah dipilihnya. Sedangkan saat ini statemen atau ibart guru kencing berdiri, maka murid kencing berlari merupakan dampak kurang diaplikasikannya ruh guru oleh guru tersebut. Misalnya, berapa banyak guru melarang rokok muridnya namun ia sendiri merokok dan masih banyak lagi yang lainnya.

Untuk masa kini dan masa akan datang di mana keadaan dunia dan zaman sangat global, terjangkitnya paradigma materialis dan hedonisme maka yang paling membedakan antara guru dulu dengan sekarang dan mungkin masa yang akan datang adalah sifat qanaah yang dimiliki oleh seorang guru. Ada fenomena menarik dimana guru dulu tidak mau menerima gaji (Arabiah Baina Yadaik, h.103), dan keadaan ini merata. Memang kita masih menjumpai guru yang bersifat qanaah plus jiwa pengabdian yang tinggi namun itu hanya bisa dijumpai di daerah-daerah pedalaman dan hampir bisa dipastikan mereka menyadari komitmen sebagai seorang guru. Sedangkan di daerah kebanyakan, adalah sebaliknya.

\section{Tawaran Solusi}

Melihat fenomena kepribadian guru yang kian hari kian bergeser dan melemah, maka diperlukan usaha untuk dapat memperbaiki keadaan ini yang nantinya secara tidak langsung akan mendongkrak profesi guru itu sendiri. Diantara yang dapat kami tawarkan disini adalah:

\section{Mempertebal Sifat Qanaah}

Guru dimasa kini dan akan datang haruslah memahami betul agar dapat bersikap qonaah, bersikap menerima tapi bukan pasif Keadaan yang bangsa yang sulit ini bukanlah harus ditangisi, tapi dijadikan tantangan untuk dapat mengeksplorasi kreativitas guru. Hal ini sudah terjadi di sekotor kehidupan lainnya seperti ekonomi. Naiknya harga BBM malah menjadikan seseorang lebih kreatif untuk membuat kompor yang berbahan bakar rendah ekonomis. Guru sendiri juga bisa bila mau, misalnya bagaimana seorang guru bertindak seminim mungkin namun tetap 
tujuan pembelajaran tercapai. Artinya mengajar jangan hanya dimaknai sebagai pekerjaan yan melelahkan, namun enjoy. Partisipasi guru dalam kegiatan penelitian (dalam hal ini penelitian tindakan kelas) seharusnya dijadikan salah satu cara untuk dapat meningkatkan ekonomi guru. Itupun kalau jeli melihat peluang seperti yang dilakukan oleh guru Bahasa Indonesia MTsN Malang I.

2. Mempertebal Komitmen

Ketika seseorang memilih profesi guru, maka saat itu juga harus disadari bahwa guru adalah pekerjaan mengabdi bukan lahan bisnis. Bila ini disadari secara total maka akan tercipta sosok guru yang sangat qanaah berkomitmen tinggi. Untuk merealisasikan hal ini maka diperlukan seleksi yang ketat dalam penerimaan mahasiswa keguruan dan penyeleksian di saat akan mengabdikan ilmunya dalam lapangan pendidikan. 


\section{DAFTAR PUSTAKA}

Bafadal, Ibrahim 2003, Peningkatan Profesionalkisme Guru Sekolah dasar dalam kerangka Manajemen Peningkatan Mutu Berbasis Sekolah, Jakarta: PT Bumi Aksara.

Hitami dan Sahrodi (2004), Menuju Penguatan Pendidikan Islam : Orientasi Pendidikan Pada Kecakapan Hidup (Life Skill) Lektur Vol X No.1 Cirebon: STAIN Cirebon Press.

Joni, Raka,1984, Wawasan Kependidikan Guru, Jakarta Depdikbud.

Langgulung, Hasan, 1998, Asas-Asas Pendidikan Islam, Pustaka Al Husna, Jakarta.

Partanto (1994), Kamus Ilmiah Populer ,Surabaya Arkola.

Mulyasa, 2003, Menjadi Kepala Sekolah Profesional, Bandung, PT Remaja Rosdakarya.

Muhaimin,2003, Wacana Pengembangan Pendidikan Islam, Yogyakarta, Pustaka Pelajar.

Sukmadinata, Nana Syaodih,2003, Landasan Psikologi Proses Pendidikan, Bandung, Remaja Rosdakarya.

Supriyadi Dedi, Mengangkat Citra dan Martabat Guru, Yogyakarta, Adicita Karya Nusda.

Tilaar, 1999, Beberapa Agenda Reformasi Pendidikan Nasional, Tera Indonesia, Magelang.

Usman, Uzer,2002, Menjadi Guru Profesional, Edisi II Cet Ke 14 Bandung, PR remaja Rosdakarya.

Winarno Surakhmad yang dimuat di Kompas Senin 26 Desember 2005, Memahami Protes Guru Lewat Puisi.

Yusuf, Slamet, Sifat-sifat yang seyogyanya dimiliki seorang guru, Makalah. , Misi guru dan bagaimana seharusnya menjadi guru, Makalah. 